\title{
Work-related stress and associated factors among employees of Hawassa industrial park, southern Ethiopia: an institutional-based cross-sectional study.
}

yohannes sime ( $\square$ johnsime400@gmail.com )

Jimma University

Hailemariam Hailesillassie

Jimma University

Arefayne Alenko

Jimma University

\section{Research Article}

Keywords: Work-related stress, Employee, Industrial park, Ethiopia

Posted Date: February 10th, 2022

DOI: https://doi.org/10.21203/rs.3.rs-1300165/v1

License: (c) (1) This work is licensed under a Creative Commons Attribution 4.0 International License.

Read Full License 


\section{Abstract}

Background: Work-related stress (WRS) is becoming an alarmingly growing public health concern worldwide. Due to globalization and changes in working conditions, people in low-income countries face growing WRS. However, despite high prevalence globally, WRS among industrial park workers is not well studied in Ethiopia.Thus; the aim of this study was to assess work-related stress and associated factors among employees of Hawassa industrial park, southern Ethiopia.

Methods: An institutional-based cross-sectional study was employed among 419 employees of Hawassa industrial park using an interviewer-administered structured questionnaire. Study participants were selected using simple random sampling technique. Data was collected by face-to-face interview. A workplace stress scale (WPSS) was used to assess work-related stress. The collected data were coded and entered into EPI data 4.6 and exported to SPSS version 26 for analysis. Multivariable logistic regression analysis was conducted to identify associated factors. The statistical significance was considered at P-value $<0.05$.

Result: The Overall prevalence of work-related stress was $47.5 \%, 95 \% \mathrm{Cl}(43.2,52.1)$. Variables such as temporary employment [AOR=0.41,95\% $\mathrm{Cl}(0.26-0.64)$ ], poor working condition [AOR $=2.12,95 \% \mathrm{Cl}(1.32$ $3.43)]$, work experience $<21 / 2 \mathrm{yr}[\mathrm{AOR}=3.11,95 \% \mathrm{Cl}(1.95-4.96)]$, poor learning opportunity [AOR=1.82, $95 \% \mathrm{Cl}(1.10-2.30)$ ], poor organizational support [AOR $=1.70,95 \% \mathrm{Cl}(1.10-2.62)$ ], current use of khat [AOR $=2.52,95 \% \mathrm{Cl}(1.28-4.99)]$ and current use of alcohol $[\mathrm{AOR}=2.27,95 \% \mathrm{Cl}(1.44-3.58)]$ were significantly associated with work-related stress.

Conclusion and recommendation: The study found high prevalence of work-related stress among employees of Hawassa industrial park. Temporary employment, poor working conditions, work experience $<2 \frac{1}{2}$ years, poor learning opportunities, poor organizational support, current khat use, and current use of alcohol were significantly associated with work-related stress. Our study finding is recommending enhancing stress management skills and primary prevention on identified risk factors to industry employees.

\section{Introduction}

Stress is a sensation of mental pressure and tension in psychological sciences. Low-stress levels may be desirable, useful, and even healthy to improve bio-psychosocial health and improve performance in its positive form. However, high stress can lead to biological, psychological, and social issues and even serious damage to people(1). A number of people who have stress caused or made themselves worse through work increases at an alarming rate and in developing countries, it becomes an issue of public health concern(2).

Work-related stress (WRS) is a harmful physical and/or emotional response when the needs of a job do not correspond with the employee's abilities, resources, or needs(3). Work-related stress occurs if the 
requirements of the job differ from the individual worker's resources and abilities to meet these requirements. Next to musculoskeletal disorders, WRS is the second most reported work-related health problem(2).

WRS causes various health concerns and impropriety. The most common health concerns include back pain, muscle aches, headache, stomach ache, bloated stomach, constipation, high blood pressure, heart problems, depression, anxiety, fatigue, annoyance, asthma. Most would inevitably have these problems(4). In addition, the quality and productivity of work decrease with these negative developments, and disease and absence increase(5).

Globally, work-related stress is a major challenge to workers and also organizations. It affects the mental and physical health of an individual and the effectiveness of an organization(6). In recent decades, globalization and technological progress have changed the world of work, introducing new forms of work organization, working relations, and employment patterns and contributing to the enhancement of WRS(7).

The magnitude of recorded work-related stress has increased over the years, and the losses for organizations and businesses have escalated afterward too. It was found that up to ( $40 \%)$ of the the cost of losing the gross domestic product per annum from 0.5 to 3.5 percent, could be attributed to WRS(8). The prevalence of work-related stress among employees of manufacturing sectors is high even though it varies across countries. It has been found to be $27.5 \%$ in Thailand(9), 23.9 in China(10), 25\% in India(11), $21.3 \%$ in Iran(12), $28 \%$ in the Democratic Republic of Congo(13), and $45.2 \%$ in Ethiopia among employees in textile factory (14).

Prior findings from the research have shown that the risk, severity, and impact of stress associated with the work have differed, depending on cultural orientation, work nature, and working environment. Some of the factors that contributed to WRS among employees were the shift work, the use of a psychoactive substance, social support, over $50 \mathrm{~h}$ of work per week, long daily working hours, high work demands, time pressure, and too many administrative tasks socio- professional factors, and demographic factors such as age(12,15-17).

Work-related stress management results in work productivity, improved labor efficiency, reduced absenteeism, sound co-operation and friendly relations with all colleagues, and good achievement of mission and vision. Some mechanisms for stress management to be used within the different organizations include a redesign of work, training in stress management; environmental design; developing stress management training, and developing organizational systems for better work and management(18). However, in our country and also Hawassa industrial park those activities are not well known and applied.

In developing countries, the magnitude of work-related stress and its determinants are one of the major public health problems(19). In Ethiopia even though the investment of industrial zones has become increasing in the past ten years, little is known about the magnitude and the determinants of the problem 
on the most at-risk manufacturing industry workers. Therefore, we conducted this study to assess workrelated stress and its associated factors among employees of Hawassa industrial park, as baseline study.

\section{Method And Materials \\ Study design}

An institutional-based cross-sectional study design was employed at Hawassa industrial park.

\section{Study Area and period}

The study was conducted at Hawassa industrial park, Hawassa city, southern Ethiopia. The Hawassa Industrial Park, which opened in July 2016, has been described as the Ethiopian government's "flagship" industrial park. It is found in Hawassa city, located $275 \mathrm{~km}$ from Addis Ababa, and the capital of Ethiopia. The city has a latitude and longitude of $7^{\circ} 3^{\prime} \mathrm{N} 38^{\circ} 28^{\prime} \mathrm{E}$ and an elevation of 1,708 meters $(5,604 \mathrm{ft})$ above sea level. The company encompasses an area of 1.3 million square meters, of which 300,000-meter square is a factory shed build-up area. Currently, 22 leading global apparel and textile companies from America, China, India, Sri Lanka as well as different local manufacturers are operating within the park(20). Currently, the company has overall 13,700 workers across 52 shades and around $80 \%$ of them are female. The study was conducted from August 1 to 30,2021

\section{Source Population}

All employees work in Hawassa industrial park.

\section{Study population}

Employees who were available in their workplace during the study period

\section{Eligibility criteria}

\section{Inclusion criteria}

The study included employees who were currently working in the industry park.

\section{Exclusion criteria}


Those employees who were seriously ill, on annual leave or maternity leave during the data collection period were excluded from the study.

\section{Sampling procedure and sampling technique}

\section{Sample size estimation}

The sample size required for the study was calculated using a single population proportion formula by considering an estimated prevalence of work-related stress to be $45.2 \%$, from the study conducted in Bahir Dar Textile Factory north-west Ethiopia, a 5\% margin of error, a $95 \%$ confidence interval, and $10 \%$ non-response rate.

$$
\mathrm{n}=\frac{\mathrm{Z}^{2} \mathrm{P}(1-\mathrm{P})}{\mathrm{d}^{2}}=\frac{1.96^{2} 0.452(1-0.452)}{0.05^{2}}
$$

Where $\mathrm{n}$ is the sample size, $\mathrm{P}$ is expected prevalence (proportion) of work-related stress, $d=$ margin of error and Z = standard score corresponds to 1.96 .

Therefore the total sample size was determined by using the above formula

$$
\begin{aligned}
& \mathrm{P}=45.2 \% \\
& \mathrm{Z}=1.96 \text { at } 95 \% \mathrm{CI} \\
& \mathrm{d}=5 \%(0.05) \\
& \mathrm{n}=\frac{1.96^{2} 0.452(1-0.452)}{0.05^{2}}=380.62=381
\end{aligned}
$$

By considering $10 \%$ non-response rate the final sample size for the study was $n=419$

\section{Sampling procedure}

First the total list of employees in the Hawassa industrial park was taken from the human resource office. Then a simple random sampling technique was employed through the computer generation random 
method by using Microsoft excel to select all 419 samples from the total list of employees. Finally the data was collected from the selected samples at their corresponding working place.

\section{Study variable}

\section{Dependent variable}

Work - related stress (Yes/No)

\section{Independent variable}

\section{Socio demographic factors}

Age, Gender, Religion, Marital status, Educational status, Types of employment, Income, Family size, Types of work, Position at work.

\section{Organizational factors}

Working conditions, Job security, Experience in the current organization, Working hours, Organizational support, Eemployee recognition, Overtime work.

\section{Job content factors}

Time pressure, Job control, Opportunity to learn, Interactions with machines, Workplace violence, Physical environment

\section{Substance use}

Alcohol use, Khat use, Tobacco use, Cannabis use, $>1$ substance use

\section{Health related factors}

Chronic medical illness and Acute illness

\section{Operational definition:}


Work related stress: A sum score below 60 of workplace stress scale was classified as having a workrelated stress among participants(21).

Working condition: Poor working conditions was considered with the summed scores of participants' on questions to assess working condition are less than $10(15,22)$.

Organizational support: Poor organizational support considered with the summed scores of participants' on questions to assess organizational support was less than 7(22).

Temporary employee: employees those who had no permanent contract or recognition letter as permamanent employee from the organization.

Time pressure: High time pressure was defined as the summed scores of participants' on questions to assess time pressure more than 10(15).

\section{Data collection tool and Procedure}

A 20-point standard questionnaire (WPSS) was used to measure work-related stress. The American Institute of Stress validated this tool, which is now used in a variety of occupations. It is a standard questionnaire with a 5-point Likert scale. The scores ranged from 1 (never) to 5 (very often). The inverse scores ranged between 5 (never) and 1 (very often). For all WPSS questions, the findings were summarized, and less than 60 scores were graded as work-related stress(23). The internal consistency, cronbach's alpha coefficient of WPSS in the current study was 0.83 .

The Job Content Questionnaire (JCQ)(24), and the National Institute for Occupational Safety and Health $(\mathrm{NIOSH})$ generic questionnaires(25), inquired about organizational factors (working conditions, overtime work, experience in the organization, working hours, organizational support, employee recognition, and job security), and job content factors (time pressure, job demand, job control, resources, opportunity to learn, interactions of people with machines, illness, and physical environment). A poor working condition is the summed scores of less than 10. Poor organizational support is the summed scores of less than 7. High time pressure is the summed scores of more than 10 . The Poor physical environment is the summed score of below 9 . These instruments were used in a previous study conducted among bahirdar textile factory and dukem shoe factory employees in Ethiopia and it was valid and reliable $(14,15)$.

Screening Test for Alcohol, Smoking, and Substance (ASSIST Version 2.0) is made up of eight items that measure lifetime(Question 1 rated "yes" = 1/"no" = 0; interview stops if "no") and recent (past 3 months; question 2: interview continues for each substance used in the past 3 months only) of substance. After reviewing different literatures four questions adopted from the tool to assess thr use of tobacco, alcohol, Khat and cannabis(26).

The data were collected through an interviewer-administered structured questionnaire, through a face-toface interview. Four data collectors (Bsc nurse) were employed for one-month data collection periods and 
supervised by two supervisors (BSc psychiatry professional). The training was given for one day regarding the administration protocol of the data collection procedures for the data collectors by the main investigator.

\section{Data processing, analysis and presentation}

Before entering the data into the computer, it was checked for completeness and cleaned. The data was then coded, cleaned, and edited before being entered into EpiData version 4.6 and exported to SPSS version 26 for analysis. Frequency, tables, texts, and summary measures were used to present descriptive statistics. Using binary logistic regression, bivariate and multivariable analysis was performed to determine the relationship between each independent variable and the outcome variable. To control for all possible confounders, all variables with P0.25 in the bivariate analysis were included in the final model of multivariable analysis. At a P-value greater than 0.05 , the Hosmer-Lemeshow statistic was used to assess the goodness of fit. The statistical associations were calculated using an odds ratio with a $95 \%$ confidence interval. Using multivariate analysis in binary logistic regression, the adjusted odds ratio and 95 percent $\mathrm{Cl}$ were calculated to identify the associated factors with work-related stress. A P-value of < 0.05 was considered statistically significant in this study.

\section{Results}

\section{Socio demographic characteristics of study participants}

From the total of 419 employees, 413 participated in the study giving a response rate of $98.6 \%$. Most of the participants $295(71.4 \%)$ were female. The mean age of the participants was $26.7(S D=5.707)$ years. Of the study participants $189(45.8 \%)$ were married and more than half $212(51.3 \%)$ of the study participants were Protestant Christian religion followers. The majority $252(61.0 \%)$ of participants had a current educational status of above secondary school and about half $212(51.3 \%)$ of the study participants were a temporary employees. More than three fourth $322(78 \%)$ of the study participants were onsite workers and the majority $229(55.4 \%)$ of study participants had average monthly income (greater than 2629 ETB). (Table 1)

Table 1

Socio-demographic characteristics of employees in Hawassa industrial park in Hawassa city, South Ethiopia, September, $2021(\mathrm{~N}=413)$ 


\begin{tabular}{|c|c|c|c|}
\hline Variables & Categories & Frequency(n) & Percentage (\%) \\
\hline \multirow[t]{2}{*}{ Sex } & Male & 118 & 28.6 \\
\hline & Female & 295 & 71.4 \\
\hline \multirow[t]{3}{*}{ Age } & $18-24$ & 154 & 37.3 \\
\hline & $25-34$ & 216 & 52.3 \\
\hline & $35-44$ & 43 & 10.4 \\
\hline \multirow[t]{4}{*}{ Marital status } & Single & 196 & 47.4 \\
\hline & Married & 189 & 45.8 \\
\hline & Widowed & 14 & 3.4 \\
\hline & Divorced & 14 & 3.4 \\
\hline \multirow[t]{4}{*}{ Current educational status } & Illiterate & 15 & 3.6 \\
\hline & Primary school(1 - 8) & 16 & 3.9 \\
\hline & Secondary school $(9-12)$ & 130 & 31.5 \\
\hline & Above secondary school & 252 & 61.0 \\
\hline \multirow[t]{4}{*}{ Religion } & Protestant & 212 & 51.3 \\
\hline & Orthodox & 162 & 39.2 \\
\hline & Muslim & 38 & 9.2 \\
\hline & Other* & 1 & 0.3 \\
\hline \multirow[t]{2}{*}{ Average monthly income* } & $<2629$ ETB & 184 & 44.6 \\
\hline & $\geq 2629 \mathrm{ETB}$ & 229 & 55.4 \\
\hline \multirow[t]{2}{*}{ Types of employment } & Permanent & 201 & 48.7 \\
\hline & Temporary & 212 & 51.3 \\
\hline \multirow[t]{2}{*}{ Family size ${ }^{\star \star}$} & Less than 4 & 178 & 43.1 \\
\hline & Greater than or equal 4 & 235 & 56.9 \\
\hline \multirow[t]{2}{*}{ Types of work } & Office & 91 & 22.0 \\
\hline & Onsite & 322 & 78.0 \\
\hline \multirow[t]{2}{*}{ Position at work } & Yes & 13 & 3.1 \\
\hline & No & 400 & 96.9 \\
\hline
\end{tabular}

Notes: Other religion: Adventist **based on Ethiopia Demographic and Health Survey (EDHS) 


\section{Organizational related characteristics of respondents}

Different organizational related variables were assessed. From the total respondents more than half 210 (50.8\%) had reported poor organizational support. Most participants, 295 (71.4\%) had poor working conditions and $286(69.2 \%)$ of the study participants reported as they had poor organizational job security. More than half 225 (54.5\%) of the participant reported that they got poor recognition on their jobs from the organization. (Table 2)

\section{Table 2}

Organizational related characteristics of employees in Hawassa industrial park in Hawassa city, South Ethiopia, September, $2021(\mathrm{~N}=413)$

\begin{tabular}{|llll|}
\hline Variables & Categories & Frequency $(\mathrm{n})$ & Percentage (\%) \\
\hline Organizational support & Good & 203 & 49.2 \\
\cline { 2 - 4 } & Poor & 210 & 50.8 \\
\hline Working condition & Good & 118 & 28.6 \\
\cline { 2 - 4 } & Poor & 295 & 71.4 \\
\hline Employees recognition & Good & 127 & 30.8 \\
\cline { 2 - 4 } & Poor & 286 & 69.2 \\
\hline Work experience in years* & Good & 188 & 45.5 \\
\cline { 2 - 4 } & Poor & 225 & 54.5 \\
\hline Working hour per week ** & $<2{ }^{1} / 2$ years & 148 & 35.8 \\
\cline { 2 - 4 } & $\geq 2{ }^{1} / 2$ years & 265 & 64.2 \\
\hline Overtime working hr per month ** & $\leq 48 \mathrm{hr}$ & 394 & 95.4 \\
\cline { 2 - 4 } & $>48 \mathrm{hr}$ & 19 & 4.6 \\
\cline { 2 - 4 } & $>20 \mathrm{hr}$ & 76 & 18.4 \\
\cline { 2 - 4 } & & 337 & 81.6 \\
\hline
\end{tabular}

Note:*categorized by mean, ${ }^{* *}$ Based on Ethiopian labour proclamation 377/2003.

\section{Job content and clinical characteristics of respondents}


Regarding the job-related problems more than one-third 187 (45.3\%) of respondents had high time pressure on their job and more than half 214 (51.8\%) of participants reported low job control at their workplace. More than three fourth $313(75.8 \%)$ of study participants reported poor learning opportunities and more than half $238(57.6 \%)$ reported poor physical condition of a working environment. The study reveals almost half $196(47.5 \%)$ of respondents reported the presence of workplace violence. The study also reveals $33(8.0 \%)$ of participants reported as they have chronic medical illness: - hypertension $(n=8)$ $(1.9 \%)$, diabetes $(n=2)(0.5 \%)$, HIV/AIDS $(n=8)(1.9 \%)$ and kidney disease $(n=15)(3.6 \%)$. (Table 3)

\section{Table 3}

Job content and clinical characteristics of employees in Hawassa industrial park in Hawassa city, South Ethiopia, September, 2021 ( $N=413)$ 


\begin{tabular}{|c|c|c|c|}
\hline Variables & Categories & Frequency(n) & Percentage (\%) \\
\hline \multirow[t]{2}{*}{ Time pressure } & Low & 226 & 54.7 \\
\hline & High & 187 & 45.3 \\
\hline \multirow[t]{2}{*}{ Attention demand } & Low & 232 & 56.2 \\
\hline & High & 181 & 43.8 \\
\hline \multirow[t]{2}{*}{ Job control } & High & 199 & 48.2 \\
\hline & Low & 214 & 51.8 \\
\hline \multirow[t]{2}{*}{ Resource in working team } & Enough & 234 & 56.7 \\
\hline & Scarcity & 179 & 43.3 \\
\hline \multirow[t]{2}{*}{ Learning opportunities } & Good & 100 & 24.2 \\
\hline & Poor & 313 & 75.8 \\
\hline \multirow[t]{2}{*}{ Interaction with machine } & Good & 94 & 22.8 \\
\hline & Poor & 319 & 77.2 \\
\hline \multirow[t]{2}{*}{ Physical condition } & Good & 175 & 42.4 \\
\hline & Poor & 238 & 57.6 \\
\hline \multirow[t]{2}{*}{ Work place violence } & No & 217 & 52.5 \\
\hline & Yes & 196 & 47.5 \\
\hline \multirow[t]{2}{*}{ Chronic medical illness } & No & 380 & 92.0 \\
\hline & Yes* & 33 & 8.0 \\
\hline \multirow[t]{2}{*}{ Current illness } & Yes & 292 & 70.7 \\
\hline & No & 121 & 29.3 \\
\hline
\end{tabular}

Notes: *presence of hypertension, diabetes, HIV/AIDS or kidney disease.

\section{Substance use characteristics of respondents}

From the total study participants more than half 227 (54.9\%) had a history of any substance use at least once in their lifetime, while 153 (37.04\%) of them uses alcohol and 50 (12.1\%) of them use Khat. Almost half $219(53.02 \%)$ of respondents had a history of any substance use in the past three months, of which $146(35.4 \%)$ use alcohol and 50 (12.1\%) uses Khat (figure 1). 


\section{Prevalence of work-related stress among employees of industrial park}

The overall prevalence of work-related stress in this study was 196 (47.5\%) with 95\% Cl $(43.2,52.1)$. Among those who have work-related stress 53 (27.04\%) were males and 143(72.96\%) were females.

\section{Factors associated with work related stress among employees of industrial park}

Bivariate and multivariable analysis was done to see factors associated with work-related stress. Hence, types of employment, family size, organizational support, working condition, work experience, learning opportunity, physical environment, workplace violence, current use of alcohol, current use of khat, and current use of more than one substance were found to be associated with work-related stress on bivariate analysis and entered to multivariate analysis.Variables associated with work-related stress on bivariate analysis were checked for multicollinearity before the final model, and all the candidates for final models had Variance Inflation Factor (VIF) less than 1.2 and tolerance of greater than 0.87 . Therefore, there was no problem with collinearity. Multivariable logistic regression analyses have revealed that temporary employment, poor working condition, work experience less than two and half years, poor learning opportunity, poor organizational support, current use of khat, and current use of alcohol were significantly associated with work-related stress.

The finding from this study shows that temporary employees had a $60 \%$ reduced risk of work-related stress AOR $=0.40,95 \% \mathrm{Cl}(0.26-0.63)$ than permanent employees. The study also reveals having poor working conditions was about 2.1 times more likely to have work-related stress $A O R=2.10,95 \% \mathrm{Cl}(1.30-$ 3.39) than having good working conditions. Additionally, employees who have work experience less than two and half year were about 3.22 times more likely to have work-related stress than employees who have work experience greater than two and half years AOR $=3.22,95 \% \mathrm{Cl}(2.01-5.12)$. Similarly, employees who have poor organizational support were about 1.59 times more likely to have work-related stress $A O R=1.59,95 \% \mathrm{Cl}(1.02-2.48)$ than those employees who have good organizational support.

In addition, the odds of having work-related stress was 1.94 times higher $\mathrm{AOR}=1.94,95 \% \mathrm{Cl}(1.12-3.22)$ among employees who had poor learning opportunities as compared with employees who had good learning opportunities. Employees who report the current use of khat was about 2.35 fold more likely to have work-related stress AOR $=2.35,95 \% \mathrm{Cl}(1.19-4.67)$ than nonusers. This study has also revealed that employees who have current use of alcohol were around times more likely to have work-related stress $\mathrm{AOR}=2.14,95 \% \mathrm{Cl}(1.35-3.34)$ than employees who didn't report current use of alcohol. (Table 4)

Table 4 
Bivariate and multivariable analysis of factors associated with work-related stress among employees of Hawassa industrial park in Hawassa city, South Ethiopia, September, 2021 (N=413) 


\begin{tabular}{|c|c|c|c|c|c|c|}
\hline \multirow[t]{2}{*}{ Variables } & \multirow[t]{2}{*}{ Categories } & \multicolumn{2}{|c|}{ Work related stress } & \multirow{2}{*}{$\begin{array}{l}\text { COR \& } \\
95 \% \mathrm{Cl}\end{array}$} & \multirow{2}{*}{$\begin{array}{l}\text { AOR \& } \\
95 \% \mathrm{Cl}\end{array}$} & \multirow[t]{2}{*}{ P-value } \\
\hline & & Yes (\%) & No (\%) & & & \\
\hline \multirow{2}{*}{$\begin{array}{l}\text { Types of } \\
\text { employment }\end{array}$} & Permanent & 107(53.2) & $94(46.8)$ & 1 & 1 & 1 \\
\hline & Temporary & $89(42.0)$ & $123(58.0)$ & $\begin{array}{l}1.57(1.07- \\
2.32)\end{array}$ & $\begin{array}{l}0.40(0.26- \\
0.63)\end{array}$ & $<0.001 *$ \\
\hline \multirow[t]{2}{*}{ Family size } & $<4$ & $92(51.7)$ & $86(48.3)$ & 1 & 1 & 1 \\
\hline & $\geq 4$ & 104(43.3) & $\begin{array}{l}131 \\
(55.7)\end{array}$ & $\begin{array}{l}0.74 \\
(0.50- \\
1.10)\end{array}$ & $\begin{array}{l}0.77(0.48- \\
1.24)\end{array}$ & 0.285 \\
\hline \multirow{2}{*}{$\begin{array}{l}\text { Organizational } \\
\text { support }\end{array}$} & Good & $83(40.9)$ & $120(59.1)$ & & 1 & 1 \\
\hline & poor & 113(53.8) & $97(46.2)$ & $\begin{array}{l}1.68(1.14- \\
2.49)\end{array}$ & $\begin{array}{l}1.59(1.02- \\
2.48)\end{array}$ & $0.039 *$ \\
\hline \multirow[t]{2}{*}{$\begin{array}{l}\text { Work experience in } \\
\text { years }\end{array}$} & $<21 / 2$ year & $88(59.5)$ & $60(40.5)$ & $\begin{array}{l}2.13(1.42- \\
3.21)\end{array}$ & $\begin{array}{l}3.22(2.01- \\
5.12)\end{array}$ & $<0.001 *$ \\
\hline & $\geq 21 / 2$ year & 108(40.8) & 157(59.2) & 1 & 1 & 1 \\
\hline \multirow{2}{*}{$\begin{array}{l}\text { Learning } \\
\text { opportunity }\end{array}$} & Good & $44(38.9)$ & $69(61.1)$ & 1 & 1 & 1 \\
\hline & Poor & $152(50.7)$ & 148(49.3) & $\begin{array}{l}1.61 \\
(1.04- \\
2.50)\end{array}$ & $\begin{array}{l}1.94(1.12- \\
3.22)\end{array}$ & $0.011^{*}$ \\
\hline \multirow[t]{2}{*}{ Working condition } & Good & $41(34.7)$ & $77(65.3)$ & 1 & 1 & 1 \\
\hline & Poor & $155(52.5)$ & $140(47.5)$ & $\begin{array}{l}2.07(1.33- \\
3.23)\end{array}$ & $\begin{array}{l}2.10(1.30- \\
3.39)\end{array}$ & $0.003^{*}$ \\
\hline \multirow{2}{*}{$\begin{array}{l}\text { Physical } \\
\text { environment }\end{array}$} & good & 71(40.6) & $104(59.4)$ & 1 & 1 & 1 \\
\hline & poor & $125(52.5)$ & $113(47.5)$ & $\begin{array}{l}1.62(1.09- \\
2.40)\end{array}$ & $\begin{array}{l}1.51(.97- \\
2.36)\end{array}$ & 0.070 \\
\hline \multirow[t]{2}{*}{ Workplace violence } & No & $90(41.5)$ & $127(58.5)$ & 1 & 1 & 1 \\
\hline & Yes & 106(54.1) & $90(45.9)$ & $\begin{array}{l}1.66(1.13- \\
2.45)\end{array}$ & $\begin{array}{l}1.38(0.87- \\
2.20)\end{array}$ & 0.173 \\
\hline \multirow[t]{2}{*}{ Current use of khat } & No & $165(45.5)$ & 198(54.5) & 1 & 1 & 1 \\
\hline & Yes & $31(62.0)$ & 19(38.0) & $\begin{array}{l}1.96(1.07- \\
3.59)\end{array}$ & $\begin{array}{l}2.35(1.19- \\
4.67)\end{array}$ & $0.014^{*}$ \\
\hline \multirow{2}{*}{$\begin{array}{l}\text { Current use of } \\
\text { alcohol }\end{array}$} & No & 111(41.6) & $156(58.4)$ & 1 & 1 & 1 \\
\hline & Yes & $85(58.2)$ & $61(41.8)$ & $\begin{array}{l}1.96(1.30- \\
2.95)\end{array}$ & $\begin{array}{l}2.14(1.35- \\
3.34)\end{array}$ & $0.001 *$ \\
\hline Current use of $>1$ & No & 183(46.6) & $210(53.4)$ & 1 & 1 & 1 \\
\hline
\end{tabular}


substance

Yes $\quad$ 13(65.0) 7(35.0)

2.13(0.83-

$5.46)$

$1.05(.34-$

$3.24)$

0.934

*Variables with significant association at $p$-value $<0.05, \quad 1=$ reference category

\section{Discussion}

Stress in the workplace is a worldwide public health problem. Studies in African countries focusing on work stress, especially among industrial park workers, are scarce. The overall prevalence of work-related stress among employees was found to be $47.5 \%$ with $95 \% \mathrm{Cl}(43.2,52.1)$. This finding was comparable with those studies done among vehicle repair workers in India(27) and Bahirdar textile factory workers, Ethiopia(14) where the preavalence of work-related stress was reported as $47 \%$ and $45.2 \%$ respectively.

Even so, the finding of the current study was higher than those studies done in Dukem shoe manufacturing, Ethiopia, 40.4\%(15), democratic republic of Congo, 28\%(13), India, 25\%(28), Iran, 21.3\% (29), Thailand, 27.5\%(30), Bristol City, 20\%(31) and Vietnam, 20.7\%(32). The reported discrepancies might be explained by that developed countries have organized safety precautions and facilitated access in advance to health and safety training with a better socio-economic status. They have also betterimproved levels of health-care services and enforcement regulations than developing countries (except for those Dukem shoe manufacturing and congo)(33). For the study done in Congo variation in sociocultural, study setting, and tools used to assess work-related stress might be possible explanations. They have used self-administered (Karasek and Siegrist's scale) while interviewer-administered (workplace stress scale) was used for the current study. In addition, the discrepancy observed with the study done at Dukem shoe manufacturing might be possibly explained by difference in study setting.

However, the current study finding is lower than studies done in Pakistan among medical educators(34) and Iran among nurses(35) where the prevalence of work-related stress was reported as $94 \%$, and $68 \%$ respectively. The possible explanation for the difference observed might be the variation of the study population and the difference in sample size. The first study was done among 111 medical educators in one private college. Most of the educators in this college take on their teaching role in addition to their clinical activities, which might lead the individuals to more stressful conditions. In the study done among nurses in Iran, the sample size was 250 and they used different tools (OSIPOW) which assess three dimensions of work adjustment, occupational stresses, psychological strain, and coping resources to assess stress at the workplace. In addition, the work nature of their study population had high workloads and needs the delivery of empathetic, culturally sensitive, proficient, and moral care in the working environment with increasing responsibility. On that account, the stated factors might be the possible explanation for the discrepancy observed with the current study. 
In the present study, temporary employment was found to be negatively associated with work-related stress among employees. This finding is reconcilable with studies done in Norway(36) and Japan(37). This detection might be explained by that the average level of effort and effort-reward imbalance which may have been influenced by their work is higher among permanent workers than temporary. In addition, permanent workers might be influenced by a commitment that the employer has made to them by entering into a permanent employment agreements, which might expose them to more pressure to achieve(38).

Outcomes from this study reveal that poor organizational support for employees was found to be an independent predictor of work-related stress. This is in line with the studies done in Nigeria(39), Sweden(40), and Dukem, Ethiopia(15). The possible explanation for this result might be employees whose employers provide insufficient support are often frustrated, apathetic, and might have poor achievement. As a consequence, this may lead to unsafe work practices, increased staff turnover, and even illness(7).

In the current study having work experiences less than two and half years was found to be significantly associated with work-related stress among employees. This is congruous with studies done in Egypt(41) and Dukem, Ethiopia(15). Less experience of interaction with a machine, working environment, and getting new experience might be the possible explanation for the association found.

This study also reveals poor learning opportunities as independent predictors of work-related stress among employees. The findings from the study conducted in Malaysia(42) and Gondar, Ethiopia(43) concur with the association. Dealing with a certain fear of not having career development due to a lack of upgrading educational status resulting in absence of learning opportunities might be the possible explanation for the finding(44).

Finding from this study indicates poor working condition was a risk factor for having work-related stress among employees. This result is agreeing with the study done in Iran(45), India(46), and Ghana(47). The possible explanation for this association might be that employees who have a discordant relation ship with supervisors, colleagues and also uncomfortable feelings towards their work will have more stress related to their job than others.

In the current study, current use of khat had a significant positive association with work-related stress among employees. The result observed in studies conducted at the bahirdar textile factory(14) and the amhara region, Ethiopia(48) is consistent with the finding. The time spent chewing khat may influence the working time of the individuals and also as the employees spent more time chewing khat they might experience the feeling of guilty and self-blame, which leads to frustration and stress in the long run(48).

In the present study current use of alcohol was also found to be independent predictor of work-related stress. This finding is consistent with studies conducted in the USA (49) and Germany(50). The Psychosocial and direct effects of alcohol on the brain might result in stress among employees. In addition, inconsistencies of employees' work performance and rewards related to that can cause 
unanticipated negative consequences among employees and this may lead to starting alcohol use as a coping(51).

\section{Conclusion}

The prevalence of work-related stress among employees of Hawassa industrial park was high. Temporary employment, poor working condition, work experience less than two and half years, poor learning opportunity, poor organizational support, current use khat and current use of alcohol were significantly associated with work-related stress. Enhancing stress management skills and primary prevention on identified risk factors was recommended.

\section{Declarations}

\section{Ethical Considerations}

The ethical clearance was obtained from the institutional review board of Jimma University (reference number:- THRPG1/338/21) before actual data collection and a permission letter was obtained from Hawassa industrial park. The objective and purpose of the study were verified briefly to the study participants and confidentiality was assured. Finally, informed consent was obtained from all study participants before conducting the interview. All methods were performed in accordance with relevant guidelines and regulations. All protection measurements for COVID-19 were taken.

\section{Consent for publication}

Not applicable

\section{Availability of data and materials}

The datasets used and/or analyzed during the current study are not publicly available to keep confidentiality of study participants but are available upon reasonable request from the corresponding author.

\section{Abbreviations}

AOR: Adjusted Odds Rratio; Cl: Confidence interval; COR: Crude Odds Ratio; SD: standard deviation; SE: standard error; SPSS: Statistical package for social sciences; WPSS: Workplace Stress Scale; WRS; Work-related Stress;

\section{Competing interests}


The authors declare that they have no competing interests

\section{Funding}

This research was funded by Jimma University. All financial supports for data collection, supervision of the study analysis, and interpretation of the data were covered by Jimma University. The funder had no role in the design of the study, collection, analysis and interpretation of data, and in the writing manuscript.

\section{Authors contributions}

YS conceived study designed, collected, analyzed, interpreted data and drafted the manuscript for important intellectual content; $\mathrm{AA}$ and $\mathrm{HH}$ conceived study designed, interpreted data and review the manuscript for important intellectual content

\section{Acknowledgements}

We would like to express our gratitude to Jimma University faculty of Medical Sciences for providing the research funding. We are grateful to all the data collectors, supervisors, and study participants for their important contribution to this study.

\section{References}

1. Shahsavarani AM, Azad E, Abadi M, Kalkhoran MH. Stress: Facts and Theories through Literature Review. Int J Med Rev. 2015;2(2).

2. European Agency for Safety and Health at Work. OSH in figures: stress at work - facts and figures. Office for Official Publications of the European Communities. 2009. 143 p.

3. Executive H and S. Work-related stress, anxiety or depression statistics in Great Britain , 2019. Annu Stat [Internet]. 2019;1-9.

4. Houtman I, Jettinghoff K. Raising awareness of stress at work in developing countries. Prot Work Heal Ser [Internet]. 2007;(6):1-51.

5. Hoboubi N, Choobineh A, Kamari Ghanavati F, Keshavarzi S, Akbar Hosseini A. The Impact of Job Stress and Job Satisfaction on Workforce Productivity in an Iranian Petrochemical Industry. Saf Health Work [Internet]. 2017;8(1):67-71.

6. Ennals R. Work Organisation. Work Life 2000 Yearb 3. 2001;24-44.

7. International Labour Organization. Workplace Stress: a collective challenge [Internet]. WORKPLACE STRESS: A collective challenge WORLD. 2016. 57 p. 
8. Hoel H, Sparks K, Cooper CL. The cost of violence/stress at work and the benefits of a violence/stress-free working environment. Geneva Int Labour Organ [Internet]. 2001;1-81.

9. Sein MM, Howteerakul N, Suwannapong $\mathrm{N} J J$. Job strain among rubber-glove-factory workers in central Thailand. Ind Heal. 2010;48(4):503-10.

10. Siu OL. Occupational stress among factory workers in Hong Kong and China: a comparison study. 1996;(39).

11. Rafiq R. Social Support and its impact on Job Stress among Cement Industry Workers: ( A Comparative Study ). Int J Manag Commer Innov. 2015;3(1):338-46.

12. I $Æ$. related unintentional injuries among Iranian car manufacturing workers. 2008;14(3):697-703.

13. Kitronza PL, Mairiaux P. Occupational stress among textile workers in the democratic republic of congo. Trop Med Health. 2015;43(4):223-31.

14. Belete H, Ergetie T, Ali T, Birhanu S, Belete T. Work-related stress and associated factors among textile factory employees in Northwest Ethiopia: A cross-sectional study. Psychol Res Behav Manag. 2020;13:1071-8.

15. Etefa MM, Teklu MG, Teshome DF. Work related stress and associated factors among Huajian shoe manufacturing employees in Dukem town, central Ethiopia. BMC Res Notes [Internet]. 2018;11(1):16.

16. Mulugeta H, Tamene A, Ashenafi T, Thygerson SM, Baxter ND. Workplace stress and associated factors among vehicle repair workers in Hawassa City, Southern Ethiopia. PLoS One [Internet]. 2021;16(4 April):1-14.

17. Heidari H, Mahdinia M, Rahimifard H. Assessment of Job Stress and Personal-Related Factors among the Workers of a Military Industry. 2016;(January).

18. Vol . 5 No . 1 June 201389 Workplace Stress and Its Management Selamawit, Goitom Abraham Selamawit and Goitom Abraham Introduction Pressure at workplace especially in humanitarian organization is unavoidable but when it becomes excessive or unmanageable. JBAS. 2013;5(1):89121.

19. World Health Organization. Global disease estimates, 2000-2016. WHO [Internet]. 2018;(June).

20. Park HI. Hawassa Industrial Park Community Impact Evaluation. 2019;(February):1-7.

21. Gebeyehu S, Zeleke B. Workplace stress and associated factors among healthcare professionals working in public health care facilities in Bahir Dar City, Northwest Ethiopia, 2017. BMC Res Notes [Internet]. 2019;12(1):1-5.

22. Jain AK, Giga SI, Cooper CLARYL, Pitaloka D, B. S. S, Novliadi F, et al. Scoring Key for Niosh Generic Job Stress Questionnaire. Stress Heal [Internet]. 2016;8(1):69-90.

23. Unknown. Attitudes in the American Workplace VII The Seventh Annual Labor Day Survey. Thinking. 2001;1-11.

24. Karasek R, Brisson C, Kawakami N, Houtman I, Bongers P, Amick B. The Job Content Questionnaire (JCQ): an instrument for internationally comparative assessments of psychosocial job 
characteristics. J Occup Health Psychol. 1998;3(4):322-55.

25. Safety O. NIOSH Generic Job Stress Questionnaire. 45226(513).

26. Heslop K, Ross C, Osmond B, Wynaden D. The Alcohol Smoking and Substance Involvement Screening Test (ASSIST) in an Acute Mental Health Setting. Int J Ment Health Addict. 2013;11(5):583-600.

27. Philip M, Alex RG, Sunny SS. A study on morbidity among automobile service and repair workers in an urban area of. Occup Environ Heal. 2014;18(1).

28. Mohan GM, Elangovan S, Prasad P, Krishna PR MA. Prevalence of job strain among Indian foundry shop floor workers. work. 2008;30(4):353-7.

29. Soori H, Rahimi M MH. Occupational stress and work-related unintentional injuries among Iranian car manufacturing workers. East Mediterr Heal J. 2008;14(3):697-703.

30. Sein MM, Howteerakul N. Job Strain among Rubber-Glove-Factory Workers in Central Thailand. Ind Health. 2010;503-10.

31. Smith A, Brice C, Collins A, Matthews V, Mcnamara R. The scale of occupational stress: A further analysis of the impact of demographic factors and type of job. Heal Saf Exec. 2000;

32. Minh KP. WORK-RELATED DEPRESSION AND ASSOCIATED FACTORS IN A SHOE MANUFACTURING FACTORY IN HAIPHONG CITY , VIETNAM Study design. Occup Environ Heal. 2014;27(6):950-8.

33. World Day for Safety and Health at Work 2013.

34. Investigator P, Medical L, Lecturer S, Medical L. Stress in Medical Educators Original Article. Prof med. 2012;19(3):1-18.

35. Poursadeghiyan M, Abbasi M, Mehri A, Hami M RM, MH. E. relation ship between job stress and anxiety, depression and job satisfaction in nurses in iran. Soc Sci. 2016;11(9):2349-55.

36. Eiken TE, Saksvik PØ. Policy and Practice in Health and Safety Temporary Employment as a Risk Factor for Occupational Stress and Health Temporary employment as a risk factor for occupational stress and health *. Pract Heal Saf. 2017;3996(August).

37. Mariko I, Shinobu T, Eiji Y. Job Stress and Mental Health of Permanent and Fixed-term Workers Measured by Effort-reward Imbalance Model , Depressive Complaints , and Clinic Utilization. Occup Health (Auckl). 2011;93-101.

38. Lee W, Park J, Min K, Lee K, Kim M. Association between work-related health problems and job insecurity in permanent and temporary employees. Ann Occup Environ Heal. 2013;1-9.

39. Arogundade TO, Arogundade BA, Adebajo O. The Influence of Perceived Organizational Support on Job Stress among Selected Public and Private Sector Employees in Lagos State, Nigeria. Sci Int. 2015;3(6):541-7.

40. Holmgren K, Dahlin-ivanoff S, Björkelund C, Hensing G. self-perceived health and sick-leave , in a population of employed Swedish women. BMC Public Health. 2009;10:1-10.

41. M E-K, A M, A E, H Z, K I. Detection of Stress among Workers in a Cement Factory. Egypt J Occup Med. 2020;44(2):649-62. 
42. Othman Z. Depression, Anxiety, and Stress among Secondary School Teachers in Klang , Malaysia. Int Med Journa. 2019;(March).

43. Kabito GG, Wami SD. Perceived work - related stress and its associated factors among public secondary school teachers in Gondar city : a cross - sectional study from Ethiopia. BMC Res Notes [Internet]. 2020;1-7.

44. Leka S, Nicholson PJ. Mental health in the workplace. Occup Med (Chic III). 2019;69(1):5-6.

45. Taylor P, Dianat I, Salimi A. Working conditions of Iranian hand-sewn shoe workers and associations with musculoskeletal symptoms. Ergonomics. 2014;57(December):37-41.

46. Areekkuzhiyil S. Factors Influencing the Organizational Stress among Teache rs Working in Higher Education Sector in Kerala. Res Pedagog Interv. 2014;2(January):2.

47. Agyemang CB, Nyanyofio JG, Gyamfi GD. Job Stress, Sector of Work, and Shift-Work Pattern as Correlates of Worker Health and Safety: A Study of a Manufacturing Company in Ghana. Bus Manag. 2014;9(7):59-69.

48. Atnafie SA, Muluneh NY, Getahun KA, Woredekal AT, Kahaliw W. Depression , Anxiety, Stress, and Associated Factors among Khat Chewers in Amhara Region, Northwest Ethiopia. hindawi. 2020;2020:12.

49. Gimeno D, Amick BC, Mangione TBTW. Work organization and drinking: An epidemiological comparison of two psychosocial work exposure models Work organization and drinking: an epidemiological comparison of two psychosocial work exposure models. Occup Environ Heal. 2008; (December 2020).

50. Nyberg ST, Fransson El, Alfredsson L, Bacquer D De, Bjorner JB, Hamer M, et al. Job Strain and Alcohol Intake: A Collaborative Meta- Analysis of Individual-Participant Data from 140000 Men and Women. plose one. 2012;7(7):1-7.

51. Artz B, Green CP, Heywood JS. Does Performance Pay Increase Alcohol and Drug Use? wisconsinmilwankee. 2019;

\section{Figures}




\section{substance use of respondents}

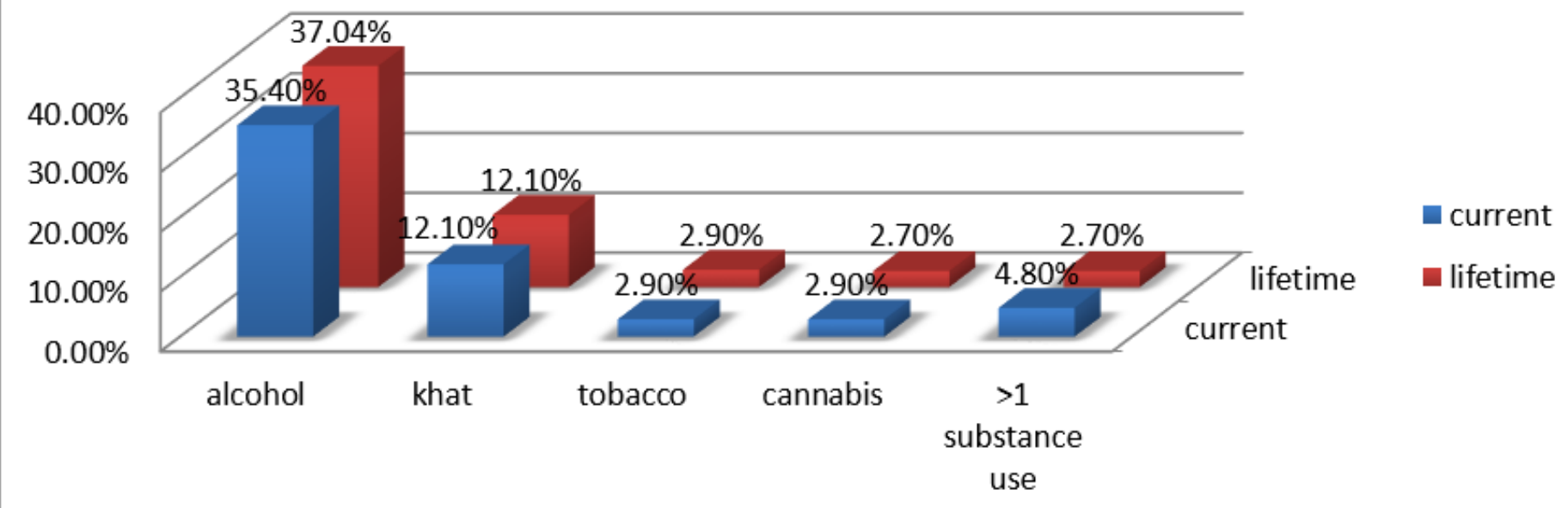

\section{Figure 1}

substance use characterstics of of employees in Hawassa industrial park in Hawassa city, South Ethiopia, September, $2021(\mathrm{~N}=413)$ 